\title{
Sosialisasi Mitigasi Bencana oleh Badan Penanggulangan Bencana Daerah Kota Ambon
}

\author{
Yustina Sopacua ${ }^{1}$, Selvianus Salakay ${ }^{2}$ \\ 1,2Fakultas Ilmu Sosial dan Ilmu Politik Universitas Pattimura, Ambon, Indonesia
}

\begin{abstract}
ABSTRAK
Provinsi Maluku sebagai salah satu provinsi yang terletak di timur Indonesia, merupakan salah satu daerah rawan bencana. Kota Ambon dan Maluku Tengah merupakan kawasan yang termasuk tingkat rawan bencana tertinggi di Provinsi Maluku. Untuk itu kesiapsiagaan diri secara mandiri sebagai bentuk penguasaan dan pengetahuan untuk menyelamatkan diri dari potensi bencana merupakan hal yang sangat penting. Minimnya pengetahuan masyarakat tentang kesiapsiagaan dan sadar bencana diakibatkan kurang intensifnya sosialisasi kepada masyarakat. Tujuan penelitian ini untuk mengetahui bentuk sosialiasi dan implementasi program oleh BPBD di Kota Ambon. Penelitian ini dilaksanakan di Kantor Badan Penanggulangan Bencana Daerah Kota Ambon, Desa Galala dan Kelurahan Batu Gajah. Penelitian ini menggunakan pendekatan deskriptif kualitatif. Teknik pengambilan data observasi lapangan dan dokumen, wawancara, dokumentasi. Teknik analisa data menggunakan metode interaktif dimana data di reduksi, disajikan dan ditarik kesimpulan. Peneliti menemukan bahwa pola komunikasi yang dibangun oleh pihak BPBD dalam menerapkan program mitigasi yakni dengan melalui komunikasi massa, dimana pemanfaatan komunikasi tradisional melalui pentungan di sekolah, melalui sosialisasi tatap muka, info resmi melalui media penyiaran radio, TVRI Maluku dan akun media sosial. Kesimpulannya, Badan Penanggulangan Bencana Daerah Kota Ambon harus memiliki langkah dan strategi, bukan saja sosialisasi secara manual seperti simulasi, pemanfaatan dunia digital, dengan tujuan untuk meminimalisir resiko bencana alam.
\end{abstract}

\begin{abstract}
Maluku Province located in eastern Indonesia, is one of the disaster-prone areas. Ambon and Central Maluku are among the highest disaster-prone areas in Maluku Province. For this reason, self-preparedness independently as a form of mastery and knowledge to save oneself from potential disasters is very important. The lack of public knowledge about disaster preparedness and awareness is due to the lack of intensive socialization to the community. The purpose of this study was to determine the form of socialization and program implementation by BPBD in Ambon City. This research was conducted at the Regional Disaster Management Agency Office of Ambon City, Galala Village and Batu Gajah Village. This research use desciptive qualitative approach. Data collection techniques are field and documents observations, interviews, documentation. The data analysis technique uses an interactive method. The researcher found that the communication pattern built by the $B P B D$ in implementing the mitigation program was through mass communication, where the use of traditional communication through clubs in schools, through face-to-face socialization, official information through radio
\end{abstract}

KATA KUNCI

Sosialisasi; mitigasi bencana; saluran komunikasi ; media; masyarakat

KEYWORDS

Socialization; disaster mitigation; channel of communication; media; community 
broadcasting media, TVRI Maluku and social media accounts. In conclusion, the Ambon City Disaster Management Agency must have steps and strategies, not only manual socialization such as simulations, the use of the digital world, with the aim of minimizing the risk of natural disasters.

\section{PENDAHULUAN}

Provinsi Maluku sebagai salah satu provinsi yang terletak di timur Indonesia, merupakan salah satu daerah rawan bencana. Berada tepat pada pertemuan empat lempeng tektonik yaitu lempeng benua Asia, lempeng benua Australia, lempeng samudra Hindia, dan lempeng samudra Pasifik, memungkinkan provinsi Maluku sangat berisiko akibat terjadinya benturan pada lempengan-lempengan tersebut. Daerah-daerah rawan gempa di Maluku di antaranya wilayah-wilayah bagian tenggara, Pulau Ambon, Seram dan Buru. Sedangkan, pusat patahan di antaranya berada di Laut Ambon dan Seram Bagian Barat.

Berdasarkan Peta Indeks Rawan Bencana yang dirilis Badan Nasional Penanggulangan Bencana (BNPB), Kota Ambon dan Maluku Tengah merupakan kawasan yang termasuk tingkat rawan bencana tertinggi di Provinsi Maluku. Dari sekitar 32 kejadian gempa bumi yang menimpa Maluku sejak tahun 1830, 13 di antaranya terjadi di Pulau Ambon. Bahkan, sejarah mencatat Ambon juga pernah 3 dari 8 kali tsunami yang pernah menghantam Maluku (Amri, 2010). Sesuai data diatas mengindikasikan bahwa Kota Ambon sangat rentan dan berpotensi terhadap resiko terjadinya bencana. Kita tahu bersama bahwa bencana merupakan peristiwa alam yang mengancam kehidupan manusia yang diakibatkan oleh faktor alam maupun karena ulah manusia. Sebagaimana yang dikemukakan Arimastuti bahwa Bencana merupakan peristiwa atau rangkaian peristiwa yang mengancam dan mengganggu kehidupan dan penghidupan masyarakat yang disebabkan, baik oleh faktor alam dan/atau faktor non alam maupun faktor manusia sehingga mengakibatkan timbulnya korban jiwa manusia, kerusakan lingkungan, kerugian harta benda, dan dampak psikologis (Arimastuti, 2011, p. 119).

Masyarakat harus memiliki pengetahuan maupun segala resiko yang dapat mengancam kehidupan mereka. Dari beberapa peristiwa bencana alam yang pernah terjadi seperti yang dikutip pada Tirto.id (Raditya, 2019), gempa dan tsunami Ambon tahun 1674, serta peristiwa yang baru-baru ini terjadi yakni sesar kairatu, pada kamis, 26 september 2019, menyebabkan rentetan gempa terjadi di 3 daerah yaitu Kota Ambon, Maluku Tengah, dan Seram Bagian Barat dan beberapa peristiwa bencana alam lainnya yang pernah terjadi di Kota Ambon.

Peneliti menganggap penelitian ini cukup penting mengingat rentetan sejarah dan pengalaman kisah bencana besar yang melanda Kota Ambon pada tahun 1674 dan 1950 serta situasi terakhir kota Ambon yang baru saja dilanda bencana Gempa bumi bermagnitudo 6,8 diikuti gempa-gempa susulan yang terjadi terus-menerus selama 3 
bulan lebih sejak 26 September sampai dengan awal desember 2019 dan isu gempa tsunami yang secara menderu mempengaruhi masyarakat Kota Ambon karena adanya hasil penelitian sejumlah peneliti asing terhadap kondisi pergerakan lempengan di pulau Ambon.

Dari pengalaman-pengalaman yang terjadi di Kota Ambon, dan sekitarnya, serta melalui proses pengamatan di lapangan yang cukup, peneliti melihat bahwa yang menjadi masalah krusial dalam pra dan paska bencana yakni minimnya pengetahuan masyarakat, hal ini bersumber dari sosialisasi yang kurang intensif secara internal maupun eksternal, sehingga peneliti tertarik untuk melakukan dan mendalami penelitian dengan judul" Sosialisasi Program Mitigasi Bencana oleh Badan Penanggulangan Bencana Daerah di Kota Ambon Tahun 2019".

Penelitian ini dilakukan untuk mengetahui bentuk sosialiasi dan implementasi program oleh BPBD di Kota Ambon, dengan permasalahan yang diangkat dalam penelitian ini adalah: Bagaimana sosialiasi program mitigasi bencana oleh badan penanggulangan bencana daerah di Kota Ambon?

Kegiatan berinteraksi antar individu dalam kehidupan bermasyarakat, sekurangkurangnya dapat mempertahankan ciri khas dari makhluk sosial, yang saling membutuhkan, dan bersosialisasi satu dengan yang lain. Sosialisasi merupakan suatu proses yang panjang, baik secara sengaja maupun tidak sengaja seseorang, dalam menjalani kehidupannya mengadakan suatu proses internalisasi (Manap, 2005, p. 56). Orientasi nilai budaya secara turun-temurun yang di tanam oleh generasi tua, kepada generasi muda, sebagai proses alamiah untuk menjaga kaidah orientasi nilai budaya dan sistem norma yang berlaku di masyarakat.

Sosialisasi dipahami secara sempit dan luas, akan tetapi pada hakekatnya, dalam teori sosiologi, sosialisasi menjadi norma dan nilai menghasilkan kesepakatan, atau, konsesus, diantara orang-orang mengenai perilaku, keyakinan yang sesuai, yang tanpa kedua hal ini, masyarakat tidak bisa hidup secara bersamaan (Jones, 2010, p. 9). Proses sosialisasi akan membentuk sistem nilai budaya yang secara langsung membentuk perilaku yang diharapkan, dan serta merta akan menjamin keteraturan sosial.

Salah satu wahana proses sosialisasi dimasyarakat adalah dunia pendidikan formal yakni sekolah. Sekolah sebagai salah satu penggerak sosialisasi, tidak sebatas memiliki fungsi pedagogik dalam arti pengajaran tapi juga memiliki fungsi membentuk pola pikir dan mengubah perilaku. Setiap anak didik akan diarahkan agar memiliki kemampuan berpikir dan bekal keilmuan yang memampukan mereka untuk terjun dalam realita sosial di masyarakat., Memberikan pemahaman tentang orientasi nilai dan system norma yang akan mempedomani aktifitas kehidupan bermasyarakat. Dari gambaran tersebut dapat dikonklusikan bahwa fungsi sekolah dalam proses sosialisasi antar lain : (1) Memberikan pengetahuan dan keterampilan yang diperlukan untuk mengembangkan 
kemampuan intelektual siswa ketika terjun dalam kehidupan bermasyarakat dan (2) Membentuk kepribadian siswa agar sesuai dengan nilai-nilai dan norma-norma yang ada di dalam masyarakat.

Proses sosialisasi yang berkembang cukup pesat yaitu melalui media massa sebagai alat atau sarana yang digunakan dalam penyampaian pesan-pesan dari sumber kepada khalayak (menerima) dengan menggunakan alat-alat komunikasi mekanis seperti surat kabar, film, radio, TV (Cangara, 2014, p. 134). Media massa merupakan sarana, channel, atau media untuk berkomunikasi kepada publik. Fungsi dari media massa selain memenuhi kebutuhan akan fantasi, juga memberikan informasi (Rakhmat, 2012, p. 65).

Media akan memainkan peranannya sesuai fungsinya. Media laksana pesan yang membentuk realita dan dinamika dalam masyarakat. Media massa digunakan sebagai wahana komunikasi yang orientasinya kepada khalayak banyak yang bersifat heterogen dan sebarannya serentak. Media massa yang yang kita kenal antara lain surat kabar, majalah, tabloid yang dikenal sebagai media cetak dan radio, televisi, yang kita sebagai media elektronik. Aspek penting yang mendasari fungsi media massa antara lain memberikan informasi, mempengaruhi sehingga terjadi perubahan sikap, dan perilaku dan memberikan hiburan kepada masyarakat. Berdasarkan jenisnya, media massa terbagi menjadi tiga bagian yaitu (1) Media Massa Cetak (Printed Media) atau media massa dicetak dalam lembaran kertas. (2) Media Massa Elektronik (Electronic Media). Jenis media massa yang isinya disebarluaskan melalui suara atau gambar dan suara dengan menggunakan teknologi elektro, seperti radio, televisi, dan film. Dan (3) Media Online (Online Media, Cybermedia), yakni media massa yang dapat kita temukan di internet (situs web).

Media massa merupakan sarana sosialisasi penting karena membantu memberikan pengetahuan atau mengonformasikan kepada masyarakat tentang sistem nilai dan norma-yang hidup dalam masyarakat. Masyarakat mengenal dan memahami orientasi nilai dan berbagai system norma yang ada dalam system sosial lewat berbagai sumber media massa. Selain itu, media massa dapat pula mengubah sikap, perilaku masyarakat bahkan dapat mengubah pendapat umum. Iklan-iklan yang ditayangkan media cetak maupun di media elektronik mempunyai potensi untuk mengubah pola konsumsi dan gaya hidup masyarakat. Media massa akan memainkan peranannya sesuai fungsinya.

Mitigasi selalu berkaitan erat dengan bencana. Mitigasi memiliki defenisi sendiri yaitu suatu upaya yang dilakukan untuk mengurangi atau bahkan menghapus kerugaian dan korban akibat terjadinya bencana alam (Fadhli, 2019, p. 5). Pengertian lainnya menurut UU NO. 24 Tahun 2007 tentang penanggulangan bencana, mitigasi ialah suatu rangkaian upaya yang dilakukan untuk meminimalisir risiko dan dampak bencana, baik melalui pembangunan infrastruktur maupun memberikan kesadaran dan kemampuan dalam menghadapi bencana. Pada dasarnya mitigasi merupakan sebuah proses yang dilakukan pada pra bencana dengan tujuan utama yaitu memenimalisir dampak bencana mulai dari 
korban jiwa, eskonomi sampai pada kerasukan SDA. Ilmu pengetahuan mengenai mitigasi bencana mulai berkembang pada abad ke-19, istilah yang awalnya yaitu "revolusi mitigasi" yakni tindakan-tindakan yang dilakukan untuk mengurangi pengaruh terhadap satu bahaya sebelum bahaya itu terjadi. Bencana dilihat sama, sebagaimana dengan penyakit, tidak dapat ditebak kedatangannya, oleh karena itu memerangi penyakit dan melawan bencana harus diperjuangkan oleh setiap orang secara bersamasama tanpa mengenal waktu.

Mitigasi bencana berdasarkan Pasal 1 ayat 6 PP No 21 Tahun 2008 tentang Penyelenggaraan Penanggulangan Bencana, merupakan upaya untuk mengurangi risiko bencana, dengan cara menempuh pengembangan fisik maupun penyadaran dan peningkatan kecakapan dalam menghadapi ancaman bencana. Menurut Fadli (2019, p. 11), kegiatan yang dilakukan dalam mitigasi adalah 1). Pengenalan dan pemantauan risiko bencana, 2). Merencanakan partisipasi penanggulangan bencana, 3). Memberikan kesadaran bencana pada masyarakat, 4). Melakukan upaya fisik, non-fisik, serta mengatur penanggulangan bencana, 5). Mengidentifikasi dan pengenalan sumber ancaman bencana, 6). Memantau penggunaan teknologi tinggi, 7). Mengawasi pelaksanaan tata ruang dan, pengelolaan lingkungan hidup, 8). Kegiatan mitigasi bencana lainnya.

Mitigasi bencana dilakukan dengan langkah dan penanganan yang serius, secara kolektif oleh semua stakeholder baik internal dan eksternal. Berdasarkan pengalaman yang terjadi, Kota Ambon pernah dilanda bencana gempa bumi, tsunami, tanah longsor, banjir hingga kebakaran. Berikut ini merupakan langkah-langkah penanganan mitigasi bencana yang terjadi di Kota Ambon : 1). Lokasi pemanfaatan lahan untuk aktivitas penting yang sudah direncanakan harus jauh, atau berada di luar dari Kawasan rawan bencana. 2). Penyesuain desain bangunan yang sesuai misal, dengan konstruksi kayu untuk tahan getaran atau gempa, atau tahan terhadap banjir, sesuai dengan kemungkinan bencana yang menimpah lokasi tempat tinggal. 3). Pembuatan dan sosialiasi kebijakan pencegahan dan penanganan bencana alam. 4) Peningkatan kewaspadaan dan kesiapsiagaan. 5). Pendidikan mengenai bencana kepada masyarakat 6). Simulasi penanganan bencana mulai dari pra hingga paska bencana yang rutin dilaksanakan setiap bulan di sekolah-sekolah agar mewujudkan kemampuan yang unggul di bidang mitigasi (diharapkan masuk sebagai kurikulum pembelajaran). 7). Meningkatkan kemampuan emosianal saat diperhadapkan dengan bencana. 8). Meningkatkan partisipasi aktif dalam penyelamatan mandiri maupun menyelamatkan orang lain.

Operasional terhadap variabel penelitian yang dituangkan secara realistis dalam indicator-indikator penelitian yang membentuknya dengan tujuan untuk menghindari kesalahan atau perbedaan penafsiran. Sesuai dengan judul penelitian yaitu: Sosialisasi program mitigasi bencana oleh badan penanggulangan bencana daerah kota Ambon. Maka variabel dari judul tersebut dioperasional atas indikator-indikator adalah media massa (saluran komunikasi) dan perilaku masyarakat. 
Ruang lingkup penelitian ini berkaitan dengan sosialisasi program mitigasi bencana pada Badan Penanggulang Bencana Daerah Kota Ambon. Penelitian ini berfokus dengan menggunakan dua teori, yaitu: sosialisasi dan mitigasi bencana. Berikut rincian konsep, yang dijabarkan dalam operasionalisasi konsep pada tabel dibawah ini:

Tabel 1. Indikator Sosialisasi dan Mitigasi Bencana

\begin{tabular}{|c|c|c|c|}
\hline Konsep & Makna & Indikator & Keterangan \\
\hline Sosialisasi & $\begin{array}{l}\text { menjadi norma dan nilai } \\
\text { menghasilkan } \\
\text { kesepakatan, atau, } \\
\text { konsesus, diantara orang- } \\
\text { orang mengenai perilaku, } \\
\text { keyakinan yang sesuai, } \\
\text { yang tanpa kedua hal ini, } \\
\text { masyarakat tidak bisa } \\
\text { hidup secara bersamaan } \\
\text { (Jones, 2010, p. 9) }\end{array}$ & $\begin{array}{l}\text { 1. Media massa } \\
\text { ( Saluran } \\
\text { komunikasi) } \\
\text { 2. Perilaku } \\
\text { masyarakat }\end{array}$ & $\begin{array}{lr}\begin{array}{l}\text { Dalam } \\
\text { pengantar }\end{array} & \text { buku } \\
\text { teori- } \\
\text { teori } & \text { sosial, } \\
\text { Saifuddin } & \text { (2010) }\end{array}$ \\
\hline $\begin{array}{l}\text { Mitigasi } \\
\text { Bencana }\end{array}$ & $\begin{array}{l}\text { merupakan upaya untuk } \\
\text { mengurangi risiko } \\
\text { bencana, dengan cara } \\
\text { menempuh } \\
\text { pengembangan fisik } \\
\begin{array}{l}\text { maupun penyadaran dan } \\
\text { peningkatan kecakapan } \\
\text { menghadapi ancaman } \\
\text { bencana. }\end{array}\end{array}$ & 1. Kecakapan & $\begin{array}{l}\text { Dalam buku } \\
\text { mitigasi bencana, } \\
\text { Fadhli (2019) }\end{array}$ \\
\hline
\end{tabular}

\section{METODOLOGI PENELITIAN}

Penelitian ini menggunakan paradigma interpretif. Dalam penelitian sosial yang menggunakan paradigma interpretif, melihat ilmu sosial sebagai analisis sistematis atas 'socially meaningful action' dimana pengamatan langsung diarahkan kepada aktor sosial dalam latar alamiah agar dapat memahami dan menafsirkan bagaimana para aktor sosial menciptakan dan memelihara dunia sosial mereka. Paradigma interpretif memandang sebuah realitas itu bersifat jamak dan holistic, dan hal ini merupakan hakikat dari sebuah realitas. Hal ini memungkinkan peneliti dapat membangun hubungan atau berinteraksi secara langsung dengan subjek di lapangan dalam hubungan yang saling mengikat (valuebound). Paradigma interpretif bertujuan untuk menjelaskan alasan subjektif dan makna dibalik suatu aksi sosial. Kemampuan peneliti dalam membangun hubungan dengan informan merupakan tindakan untuk menjamin keberhasilan dalam pendekatan paradigma interpretif. Keberhasilan peneliti ini tidak lepas dari kemampuan melakukan: 
pemahaman muncul melalui interaksi, memahami konteks, memahami pengalaman informan dan terakhir cara membuat informan membagi pemahaman (Patilima, 2004, p. $65)$.

Metode penelitian yang digunakan dalam penelitian ini merupakan metode studi kasus. Menurut Yin (2009, p. 21) menjelaskan bahwa metode studi kasus merupakan suatu metode yang tepat apabila permasalahan penelitian yang hendak dianalisa atau dicari pemecahan masalahnya berhubungan dengan orientasi kata tanya bagaimana atau mengapa. Pemilihan metode studi kasus dalam penelitian ini dirasakan oleh peneliti sangat sesuai karena peneliti dapat mendalami secara dalam dengan melakukan triangulasi data dan dokumen serta peneliti dapat memberikan pendapat.

Lebih lanjut menurut Yin mengungkapkan bahwa studi kasus merupakan jenis penelitian kualitatif, didalamnya peneliti mengeksplorasi kehidupan nyata, sistem terbatas kontemporer atau beragam sistem terbatas lainnya. jadi studi kasus harus memenuhi unsur kontemporer, spesifik dan juga unik. Dalam penelitian ini peneliti mengambil kasus "Sosialisasi Program Mitigasi Bencana Alam oleh Badan Penanggulangan Bencana Daerah di Kota Ambon Tahun 2019"

Lokasi penelitian ini dilakukan di Kantor Badan Penanggulangan Bencana Daerah (BPBD) Kota Ambon, Desa Galala dan Kelurahan Batu Gajah dari bulan Juli-September 2019.

Penelitian ini menggunakan pendekatan deskriptif kualitatif. Menurut Creswell (dalam Sugiyono, 2013, p. 82) makna pendekatan deskriptif kualitatif merupakan sebuah metode penelitian yang memanfaatkan data kualitatif dan penjabarannya dilakukan secara deskriptif. pendekatan untuk membangun dasar pengetahuan berdasarkan perspektifkonstruktif berdasarkan pemaknaan atau arti yang bersumber dari pengalaman individu, nilai-nilai sosial dan sejarah, dengan tujuan untuk membangun teori atau pola pengetahuan tertentu).

Objek Penelitian yaitu Badan Penanggulangan dan Bencana Daerah Kota Ambon, Subjek penelitian atau dalam penelitian kualitatif biasa disebut sebagai informan (kunci dan pendukung). Pemilihan informan dalam penelitian ini menggunakan Teknik purposive sampling yaitu sebuah teknik dimana peneliti secara sengaja memilih atau mengambil informan bersadarkan pertimbangan-pertimbangan tertentu secara khusus berdasarkan tujuan penelitian. (Usman \& Akbar, 2009, p. 45). Informan kunci dalam penelitian ini adalah pihak yang melakukan sosialisasi mitigasi bencana alam yaitu Kepala Kantor BPBD Kota Ambon, Pegawai Teknis Kantor BPBD Kota Ambon di Desa Galala dan Kelurahan Batu Gajah, sedangkan yang menjadi informan pendukung adalah, Perangkat Desa Galala dan Kelurahan Batu Gajah, Masyarakat yang sudah pernah mengalami bencana alam, dan generasi milleneal di Desa Galala dan Kelurahan Batu Gajah. 
Teknik pengumpulan data menurut Parsudi Suparlan (dalam Patilima, 2004, p. 14), terdapat bukti-bukti yang dijadikan fokus bagi pengumpulan data studi kasus yaitu: (1) observasi langsung di lapangan saat melakukan pra penelitian dan penelitian, (2) dokumen yang diperoleh dari subjek penelitian, (3) interview guide, (4) dokumentasi. Metode dalam mengumpulkan data ini diperlukan untuk mengungkap fenomena yang terjadi dilapangan secara jelas. Penelitian ini menggunakan dua jenis sumber data primer yaitu:

Wawancara mendalam dilakukan untuk memperoleh informasi dan data secara langsung dengan mengungkapkan pertanyaan-pertanyaan kepada subjek penelitian (Subagyo, 2006, p. 63). Proses wawancara mendalam biasanya dilakukan dengan proses tatap muka secara langsung dengan melibatkan pewawancara dan narasumber. Teknik wawancara mendalam yang dilakukan secara terstruktur, yaitu proses tanya jawab secara langsung dengan informan untuk mendapatkan data yang akurat, jelas, terinci, terdalam dan terpercaya.

Observasi merupakan teknik pengumpulan data yang sistematis terhadap gejala-gejala yang diteliti. Sutrisno Hadi (dalam Sugiyono, 2012, p. 166) mengemukakan bahwa, observasi merupakan suatu proses yang kompleks, suatu proses yang tersusun dari pelbagai proses biologis dan psikologis. Peneliti harus memusatkan perhatian pada datadata yang relevan dan mengklasifikasikan gejala dalam kelompok yang tepat serta menambah bahan persepsi tentang objek yang diamati (Usman \& Akbar, 2009, p. 52-53). Data yang diperoleh peneliti tidak hanya berpusat pada saat wawancara, melainkan proses sebelum wawancara tetapi tetap dikaitkan dengan fenomena yag terjadi. Proses tersebut membuat penelitian ini akan lebih terlihat objektif.

Dalam penelitian ini, teknik pengolahan data yang digunakan menggunakan metode interaktif yang terdiri dari reduksi data dan penyajian data yang seterusnya setelah dianalisa akan melahirkan sebuah kesimpulan. Reduksi data dapat diartikan sebagai proses dalam pemilihan data, penyederhanaan, pengabstrakan dan atau merubah data kasar yang diperoleh dari berbagai catatan penelitian di lapangan. Proses reduksi data dilakukan sejak dimulainya pengumpulan data, dengan membuat ringkasan berbagai fenomena atau indikasi yang terjadi, kemudian memberi pengkodean dan tema yang tepat, dengan berbagai rangkaian catatan yang bertujuan untuk memisahkan data atau informasi yang tidak relevan dengan tujuan dan manfaat penelitian.

Penyajian data merupakan proses pendeskripsian dan penyusunan sejumlah informasi yang telah atau sudah diolah yang memungkinkan untuk dilakukan tindakan penarikan kesimpulan. Penyajian data kualitatif dalam bentuk narasi, matriks, grafik, jaringan maupun bagan. Dirancang secara terpadu agar mudah dipahami (Usman, 2009, p. 87).

Dalam penelitian kualitatif mengenai "Sosialisasi Program Mitigasi Bencana oleh Badan Penanggulangan Bencana Daerah Kota Ambon Tahun 2019, data dianalisa menggunkan 
metode interaktif yang terdiri atas reduksi data, penyajian data dan penarikan kesimpulan. Tahapan analisis data sebagai berikut: a). Analisa data dilakukan sebelum peneliti terjun ke lapangan. Peneliti telah mengamati proses sosialisasi melalui pemberitaan mediamassa, dan website Info BMKG maupun media sosial. b). Analisa berikut yang dilakukan peneliti, adalah dengan melakukan observasi ke lapangan (pra penelitian) untuk mengumpulkan data dan informasi. Data yang diperlukan sebanyak mungkin untuk menjawab rumusan masalah penelitian. c). Analisa selanjutnya, saat peneliti secara sistematis melakukan penelitian. Informasi dari pihak-pihak yang berkaitan serta dokumen yang berkaitan dengan sosialiasi program mitigasi bencana. d). Tahapan berikutnya, adalah mereduksi data yakni memisahkan atau membuang datadata yang tidak relevan, kemudian memasukkannya ke dalam kategori-kategori agar mudah untuk dianalisis. e). Tahapan penyajian data. Penyajian data dalam bentuk narasi, bagan dan hubungan antar kategori. f). Membuat kesimpulan merupakan langkah terakhir dalam tahapan ini. Kesimpulan dibuktikan melalui data yang valid dan konsisten sesuai dengan yang diperoleh di lapangan.

Dalam penelitian kualitatif, data disebut valid apabaila dapat dicapai dengan melakukan triangulasi data dan informan (Idrus, 2009, p. 27). Triangulasi merupakan Teknik pemeriksaan data yang memanfaatkan sesuatu yang di luar data itu untuk keperluan pengecekan dan sebagai bahan pembanding terhadap data tersebut. Sedangkan menurut Moleong (2019, p. 178) membedakan empat macam triangulasi data sebagai Teknik pemeriksaan yang memanfaatkan penggunaan sumber, metode penyidik dan teori.

Data dapat memenuhi kriteria valid dan reliabel apabila sudah menemukan data jenuh yaitu kapan dan dimana serta kepada siapapun (subjek penelitian) pertanyaan penelitian diajukan, hasil jawaban tetap konsisten atau triangulasi subjek. Jika sudah sampai pada data jenuh, maka pada titik itulah peneliti sudah memiliki cukup alasan untuk menghentikan proses pengumpulan data (Idrus, 2009, p. 145).

Dalam penelitian ini, triangulasi yang dilakukan adalah triangulasi subjek dan dokumen (sumber). Patton (dalam Moleong, 2019), mengatakan bahwa triangulasi sumber data merupakan tindakan pengumpulan yang diperoleh dari berbagai sumber dengan menggunakan metode tertentu dan telah melakukan langkah pengecekan tingkat kepercayaan informasi yang diperoleh melalui waktu dan alat yang berbeda dalam metode kualitatif. Proses ini dapat dicapai melalui dua langkah yakni: 1). Membandingkan data hasil pengamatan dengan data hasil wawancara dan, 2). Membandingkan hasil wawancara dengan isi suatu dokumen yang berkaitan. 


\section{HASIL DAN PEMBAHASAN}

\section{Pemahaman Masyarakat tentang Mitigasi Bencana Alam.}

Sebagai makhluk sosial, manusia yang mendiami suatu lingkungan system sosial tentunya memiliki ciri atau kecenderungan tertentu seperti hidup bersama satu sama lain dalam arti sekurang-kurangnya terdiri atas dua orang, mereka hidup bergaul dan berinteraksi dalam kurun waktu yang cukup lama. Berkumpulnya manusia secara komunal tentunya akan menimbulkan munculnya manusia baru. Sebagai akibat dari hidup bersama, timbul sistem komunikasi dan peraturan yang mengatur hubungan mereka satu sama lain, hal ini memungkinkan munculnya kesadaran bahwa mereka merupakan satu kesatuan bersama. Kesadaran inilah yang menghidupkan kesatuan sistem sosial untuk hidup bersama sehingga menumbuhkan pola dan kebiasaan hidup yang melembaga dalam budaya mereka. Masyarakat menjadi elemen yang sangat penting, masyarakat sejatinya menempati posisi subjek, bukan objek. Jika dalam proses pra bencana, masyarkat tidak diperkuat, maka resiko-resiko, sebagai akibat dari kepanikan bisa saja terjadi. Oleh karenanya, sosialisasi mitigasi bencana berperan penting dalam meminimalisir resiko-resiko tersebut.

Masyarakat Desa Galala dan kelurahan Batu Gajah yang dikategorikan pernah mengalami dampak bencana yang menjadi peserta sosialisasi yang dilakukan oleh Badan Penanggulangan Bencana Daerah (BPBD) di Kota Ambon. Masyarakat kedua desa ini yang menjadi rujukan informan karena mereka yang sudah pernah mengalami kejadian bencana alam sebelumnya. Masyarakat desa Galala mengalami Tsunami pada 08 Oktober 1950 yang oleh masyarakat setempat di sebut dengan istilah air turun-naik. Pemerintah Desa Galala, serta generasi millineal sudah cukup responsif dalam memantau gejolaknya kondisi alam termasuk bencana alam melalui internet.

Berdasarkan informasi hasil penelitian yang di perolah dari wawancara informan yang berkaitan dengan respond dan kesadaran terhadap resiko bencana serta tindakan antisipatif terhadap bencana, dapat disimpulkan bahwa :

Kepekaan dalam merespon bencana alam, dalam hal ini masyarakat diberikan pemahaman akan karakteristik wilayah yang mereka tempati berdasarkan pengalaman di masa lampau, sehingga bencana alam berpotensi untuk kembali terjadi. Sosialisasi yang diberikan kepada msyarakat bertujuan untuk mengurangi resiko yang akan terjadi pasca bencana alam, oleh sebab itu simulasi mitigasi bencana alam dilakukan sebagai upaya konkrit dari BPBD Kota Ambon, kepada masyarakat Galala, dengan melibatkan anak sekolah dasar, guna dapat melakukan penyelamatan mandiri.

Renungan fenomena bencana alam di masa lampau, masyarakat harus memiliki orientasi nilai budaya yang berkaca pada pengalaman masa lalu. Orientasi hidup masyarakat tidak selamanya untuk masa kini dan masa akan dating saja tapi pengalaman akan masa lalu dapat menjadi pembelajaran proses hidup. Artinya bahwa, ketika kita 
mampu melakukan penyelamatan mandiri, dan berkesempatan menyelamatkan orang lain, hal ini jangan kita hindari. Proses identifikasi sangat penting, untuk meminimalisir korban bencana alam, dan manfaatkan jalur evaluasi yang telah disiapkan oleh Pemerintah melalui tanda-tanda yang terpasang di depan jalan. Hal ini mempermudah proses mitigasi bencana alam. Karena kita tidak pernah tahu kapan waktu datangnya bencana, namun dengan adanya pengetahuan dan pengalaman, kita dapat mengidentifikasi penyebabnya, kemudian berusaha untuk hidup damai dengan alam, walaupun sebenarnya hidup dan mati, taka da seorangpun yang dapat memprediksi.

Menumbuh kembangkan kesadaran dalam mengurangi resiko bencana alam, Pada dasarnya bencana alam tidak dapat diprediksi, dan sepertinya konyol untuk menghindar dari bencana alam. Hal paling mendasar yang peniliti rasakan penting, yaitu: pewaspadaan oleh masyarakat, dengan cara memberikan pengetahuan/wawasan yang kiranya komprehensif, sehingga tidak menimbulkan kekacauan di tengah masyarakat. Hal ini justru menjadi bagian paling penting dalam sosialisasi mitiigasi bencana alam, masyarakat bisa saja termakan hoax melalui media massa, dan juga by word of mouth, bahkan kepanikan akibat hoax berpotensi pada kesehatan pada generasi manapun.

Tindakan nyata yang dilakukan pada saat bencana alam, bekal yang diberikan oleh BPBD Kota Ambon kepada masyarakat galala, sekurang-kurangnya mampu diterapkan pada saat simulasi saat sosialisasi, walaupun belajar dari sesar kairatu yang terjadi pada 26 september 2019, tidak ada korban bencana alam, namun disayangkan bukan ketika korban berjatuhan. Histeris dan kepanikan yang berlebihan, dan merambah ke masyarakat di daerah lain menjadi salah satu indikator bahwa BPBD harus lebih mendalam, harus lebih sungguh-sungguh menanamkan sosialisasi mitigasi bencana alam. Peneliti menemukan bawasannya, hanya sekali BPBD turun ke lapangan, dan seolah berharap besar bahwa masyarakat mampu secara alamia menyelamatkan diri sendiri. Justru mitigasi bencana yang merupakan proses pra bencana, logika dan praktik di lapangan menjadi terbalik mitigasi bencana justru dilakukan pasca bencana alam. Mentalitas dari masyarakat sipil dan aparatur Pemerintah Kota Ambon harus segera dibenahi. Orang akan sadar, akan peka, dan akan merespon dengan tindakan nyata ketika peristiwa bencana alam terjadi dan menimpa mereka. Masyarakat tidak menggunakan kemampun berpikir kritis, padahal sangat bermanfaat guna mawas diri dan juga keluarga.

Mitigasi bencana bawasannya merupakan, program yang harus dilakukan dengan melibatkan masyarakat. Kesadaran masyarakat perlu ditingkatkan melalui berbagai mekanisme, diantaranya penyebaran informasi melalui media. Segment tindakan bencana harus menyasar mulai dari anak-anak (generasi millineal) dengan memberikan Pendidikan mitigasi bencana agar dapat dipahami bahayanya bencana sebagai satu kenyataan hidup, berani mengambil keputusan dalam wujud tindakan dan menyadari akan segala kemungkinan yang dapat terjadi akibat gempa. Keterlibatan masyarakat 
dalam proses perencanaan mitigasi kemungkinan akan melibatkan konsultasim keingintahuan serta FGD dengan stakeholders terkait.

\section{Respon Badan Penanggulangan Bencana Daerah Kota Ambon dalam menyikapi bencana yang terjadi di Kota Ambon.}

Menurut Perda Kota Ambon No 25 Tahun 2012, tentang organisasi dan tata kerja Badan Penanggulangan Bencana Daerah (BPBD) Kota Ambon, maka struktur organisasi BPBD Kota Ambon sebagaimana format sturktur BPBD lainnya terdiri dari yaitu : kepala, unsur pengarah dan unsur pelaksana. Berdasarkan uraian fungsi dan tugas, khusus untuk program mitigasi bencana, berada di bawah naungan unsur pelaksana yakni bidang pencegahan dan kesiapsiagaan yang memiliki dua seksi yakni seksi pencegahan dan seksi kesiapsiagaan.

Bidang Pencegahan dan Kesiapsiagaan mempunyai tugas melakukan koordinasi dalam pelaksanaan kebijakan di bidang Pencegahan, Mitigasi dan Kesiapsiagaan pada prabencana serta pemberdayaan masyarakat. Untuk melaksanakan tugas tersebut, Bidang Pencegahan dan Kesiapsiagaan mempunyai fungsi Merumuskan kebijakan dibidang Pencegahan, Mitigasi dan Kesiapsiagaan pada prabencana serta pemberdayaan masyarakat; Mengkoordinasikan dan melaksanakan kebijakan di bidang dibidang Pencegahan, Mitigasi dan Kesiapsiagaan pada prabencana serta pemberdayaan masyarakat; Melaksanakan hubungan kerja dengan Instansi atau Lembaga terkait di bidang dibidang Pencegahan, Mitigasi dan Kesiapsiagaan pada prabencana serta pemberdayaan masyarakat; Melakukan pemantauan, evaluasi, dan analisis pelaporan tentang pelaksanaan kebijakan di bidang dibidang Pencegahan, Mitigasi dan Kesiapsiagaan pada prabencana serta pemberdayaan masyarakat; Melaksanakan Dokumen Pelaksanaan Anggaran (DPA) dan Dokumen Perubahan Pelaksanaan Anggaran (DPPA); Melaksanakan Standar Pelayanan (SP) dan Standar Operasional Prosedur (SOP); Melaksanakan Standar Pelayanan Minimal (SPM), Mengevaluasi dan melaporkan pelaksanaan tugas dan fungsi, dan; Melaksanakan tugas lain yang diberikan oleh Kepala Bidang sesuai dengan tugasnya.

Bidang Pencegahan dan Kesiapsiagaan terdiri dari: (a) Seksi Pencegahan. Seksi Pencegahan mempunyai tugas melakukan koordinasi dan melaksanakan kebijakan di Bidang Pencegahan dan Mitigasi Bencana. Untuk melaksanakan tugas tesebut Seksi Pencegahan mempunyai tugas: Menyiapkan bahan perumusan dan pelaksanaan kebijakan teknis bidang pencegahan dan mitigasi bencana; Menyiapkan bahan pengkoordinasian dan pelaksanaan kebijakan di bidang pencegahan dan mitigasi bencana; Menyiapkan bahan pelaksanaan hubungan kerja dengan instasi atau lembaga terkait di bidang pencegahan dan mitigasi bencana; Menyiapkan bahan pemantauan, evaluasi dan analisis pelaporan tentang pelaksanaan kebijakan di bidang pencegahan dan mitigasi bencana; Melaksanakan Dokumen Pelaksanaan Anggaran (DPA) dan Dokumen Perubahan Pelaksanaan Anggaran (DPPA); Melaksanakan Standar Pelayanan (SP) dan Standar Operasional Prosedur (SOP), Melaksanakan Standar Pelayanan Minimal (SPM), 
Mengevaluasi dan melaporkan pelaksanaan tugas dan fungsi, dan; Melaksanakan tugas lain yang diberikan oleh Kepala Bidang sesuai dengan tugasnya. (b) Seksi Kesiapsiagaan. Seksi Kesiapsiagaan Bencana bertugas untuk berkoordinasi dan melaksanakan kebijakan di Bidang Kesiapsiagaan pada prabencana serta pemberdayaan masyarakat. Untuk melaksanakan tugas tersebut Seksi kesiapsiagaan Bencana mempunyai fungsi: Menyiapkan bahan perumusan dan pelaksanaan kebijakan teknis bidang kesiapsiagaan pada prabencana serta pemberdayaan masyarakat; Menyiapkan bahan koordinasi dan pelaksanaan kebijakan di bidang kesiapsiagaan pada prabencana serta pemberdayaan masyarakat; Menyiapkan bahan pelaksanaan hubungan kerja dengan instansi atau lembaga terkait dibidang kesiapsiagaan pada prabencana serta pemberdayaan masyarakat; Menyiapkan bahan pemantauan, evaluasi dan analisis pelaporan tentang pelaksanaan kebijakan dibidang kesiapsiagaan pada prabencana serta pemberdayaan masyarakat; Melaksanakan Dokumen Pelaksanaan Anggaran (DPA) dan Dokumen Perubahan Pelaksanaan Anggaran (DPPA); Melaksanakan Standar Pelayanan (SP) dan Standar Operasional Prosedur (SOP), Melaksanakan Standar Pelayanan Minimal (SPM), Mengevaluasi dan melaporkan pelaksanaan tugas dan fungsi, dan; Melaksanakan tugas lain yang diberikan oleh Kepala Bidang sesuai dengan tugasnya.

Dalam upaya merespon bencana alam yang terjadi di Kota Ambon, yang disesuaikan juga dengan uraian tugas dan fungsi diatas, maka perlu adanya kerja kolektif dari semua pihak, baik dari internal maupun eksternal. Disadari sungguh, bahwa minimnya sumber daya manusia, bukan menjadi hal baru yang terjadi di Indonesia, khususnya Kota Ambon. Berdasarkan RENSTRA BPBD Kota Ambon tahun 2017-2022, jumplah pegawai sebanyak 33 orang, dengan rincian ASN sebanyak 32 orang (magister 5 orang, sarjana 18 orang dan lulusan SMA 9 orang, ditambah dengan pegawai kontrak sebanyak 1 orang.

Jumlah pegawai sesuai rincian diatas, dirasakan cukup mustahil bisa mengurusi masyarakat Kota Ambon sebanyak 411.467 jiwa (data bps, bulan juni 2017), belum lagi dalam penganggaran yang minim dari pusat. Akan tetapi, niat dari BPBD dalam mengupayakan masyarakat Kota Ambon yang tangguh bencana tidak dapat disepelekan. Melalui berbagai program seperti sosialisasi sudah sering dilakukan di berbagai desa dan kelurahan di Kota Ambon.

Proses sosialisasi kepada masyarakat juga dilakukan melalui komunikasi langsung secara tatap muka di sekolah-sekolah melalui kegiatan simulasi sadar bencana kepada anak sekolah sejak usia dini maupun komunikasi menggunakan media melalui iklan-iklan layangan masyarakat maupun bentuk kegiatan konkrit pencegahan bencana yang dipublikasikan lewat media massa. Komunikasi dalam konteks bencana seperti komunikasi penyiaran, berperan penting dalam menyebarkan informasi bencana kepada masyarakat (Junaedi, 2011, p. 213). Proses sosialisasi oleh BPBD Kota Ambon, juga lewat media online yakni lewat website resmi pemerintah Kota Ambon maupun BPBD Kota Ambon sendiri. 
Belajar dari peristiwa di Jepang, di ketahui bersama bahwa Indonesia dan Jepang samasama berada pada jalur Ring of Fire atau jalur Cincin Api. Keduanya berada di zona jalur Cincin Api Pasifik yang aktif dengan persentasi gempa bumi sekitar 90\% di dunia. Menurut data United States Geological Survey (USGS), Indonesia yang berada di zona seismik yang sangat aktif dan merupakan satu-satunya negara dengan frekuensi gempa bumi terbanyak di dunia. Intensitas gempa terjadi merata di darat dan di laut, dibandingkan dengan Jepang yang lebih banyak gempa buminya terjadi di daratan. Bencana gempa tidak ada yang dapat memprediksikan kejadiannya dan belum ada teknologi yang mampu mendeteksi ataupun menghentikan aktivitas lempeng aktif bumi yang terus bergerak. Namun demikian, pemanfaatan teknologi masih dapat manfaatkan untuk melakukan fungsi peringatan dini sehingga risiko bencana dapat dikurangi.

Pengetahuan akan bencana bukan hanya sekedar mengetahui, lebih dari pada itu, sekurang-kurangnya setiap orang harus mampu melakukan penyelamatan mandiri, yakni mampu menyelamatkan diri sendiri setelah memahami dan mengetahui resiko bencana dan penyelamatan secara mandiri. Namun keterbatasn-keterbatasan, tidak dapat dihindari seperti akses dan juga minimnya anggaran. Ramli, dalam Soehatman (2010, p. 27) bahwa mengelola bencana tidak bisa dilakukan secara dadakan namun harus terencana dengan manajemen yang baik sebelum terjadi bencana. Penanggulangan bencana merupakan serangkaian upaya penetapan kebijakan pembangunan terkait pencegahan, tanggap darurat, dan rehabilitasi.

Komunikasi atau koordinasi penanggulangan bencana sangat diperlukan untuk memperoleh tujuan yaitu agar penanganan korban bencana berjalan secara efektif dan efisien. Efektif berarti bahwa tujuan dapat dicapai sesuai dengan perencanaan, sementara efisien berarti bahwa tugas yang ada dilaksanakan secara benar, terorganisir, dan sesuai dengan jadwal. Guna memperoleh efektifitas dan optimalisasi sumberdaya diperlukan persyaratan tertentu antara lain; (1) Komunikasi berbagai arah dari berbagai pihak yang dikoordinasikan; (2) Kepemimpinan dan motivasi yang kuat di saat krisis; (3) Kerjasama dan kemitraan antara berbagai pihak; (4) Koordinasi yang harmonis. Keempat syarat tersebut dipadukan untuk menyusun; Perencanaan, Pengorganisasian, Pelaksanaan, dan Evaluasi Penanggulangan Bencana. Koordinasi memerlukan; (1) Manajemen penanggulangan masalah bencana yang baik; (2) Adanya tujuan, peran dan tanggung jawab yang jelas dari organisasi; (3) Sumber daya dan waktu yang akan membuat koordinasi berjalan; (4) Jalannya koordinasi berdasarkan adanya pertukaran informasi dari berbagai sumber informasi yang berbeda (Lestari, 2007).

Berdasarkan hasil pengamatan yang dilakukan, disertai dengan wawancara terbuka dengan pihak BPBD, maupun stakeholder yang terkait terhitung bulan juni - bulan September 2019. Peneliti menemukan bahwa pola komunikasi yang dibangun oleh pihak BPBD dalam menerapkan program mitigasi yakni dengan melalui komunikasi massa, dimana pemanfaatan komunikasi tradisional melalui pentungan di sekolah, melalui sosialisasi tatap muka (world of mouth), maupun info resmi melalui media penyiaran 
radio, TVRI Maluku dan akun media sosial. Saluran komunikasi yang beragam, tidak selalui memberikan garansi terbaik. Pemilihan media yang tepat bukan dilihat dari berapa banyak orang yang melihat atau mendengar, tapi seberapa dalam pengetahuan tentang bencana mampu diserap oleh masyarakat Kota Ambon.

Pesatnya perkembangan teknologi media streaming di era masyarakat informasi sekarang ini, memungkinkan kemudahan bagi pemerintah lewat instansi terkait dalam memikirkan langkah terbaik dan strategis dalam merespon datangnya bencana secara tiba-tiba, terutama yang berhubungan dengan penggalangan dan distribusi bantuan. Berbagai langkah dan tindakan konkrit yang dilakukan harus lebih taktis, sehingga diperoleh hasil yang cepat dan maksimal. Dibutuhkan sinergi komunikasi antara komunikasi interpersonal, kelompok, dan melalui media massa serta media baru dalam pengelolaan bencana, sehingga hasil konkrit dari proses mitigasi bencana atau pengurangan resiko bencana bisa tercapai. Proses komunikasi yang dibangun secara interpersonal dilakukan antara pemerintah dan korban dalam hal ini BPBD Kota Ambon dengan korban bencana menggunakan prinsip-prinsip: keterbukaan, kejujuran, saling merespon secara positif, simpati dan empati. Hal ini juga dilakukan dengan para relawan yang secara kelompok berkepentingan dengan penanggulangan bencana seperti Tagana. Kelompok-kelompok ini secara organisatoris sangat dibutuhkan karena mereka merupakan bagian dari wadah atau kelompok yang meresponi penangulangan bencana.

Sosialisasi tidak hadir begitu saja, di dalam sosialisasi dibutuhkan kemampuan dalam berkomunikasi dan berkoordinasi, hal ini semata-mata karena tidak semua orang memiliki kemampuan menyerap informasi yang sama. Tingkat pendidikan dan budaya dari masing-masing latar belakang keluarga menjadi penyebab, sehingga secara intens, Pemerintah harus melakukan sosialisasi melalui cara-cara yang strategis.

\section{SIMPULAN}

Banyaknya peristiwa bencana alam yang terjadi di Kota Ambon, tidak membuat Pemerintah secara umum, dan masyarakat pada khususnya untuk hilang akal dalam mengelolah bencana. Sekurang-kurangnya, masyarakat harus memiliki pengetahuan tentang bencana yang diperoleh secara mandiri melaluipemberitaan media, sekalipun sebenarnya hal ini merupakan tanggung jawab Pemerintah dalam memberikan informasi dan edukasi. Proses pengendalian diri, diharapkan mampu dikuasai oleh setiap individu. Artinya bahwa setiap orang harus bisa mengelolah atau me-manage bencana secara pribadi. Tentu saja, peran Pemerintah Kota Ambon melalui Badan Penanggulangan Bencana Daerah Kota Ambon sangat berpengaruh. Artikulasi dan praktik, harus disesuaikan, tidak hanya symbol belaka, secara retorika mampu membangkitkan semangat masyarakat untuk tangguh bencana, tetapi terlepas dari semua dinamika yang terjadi, semua harus terintegrasi, bekerja kolektif secara masif. Badan Penanggulangan Bencana Daerah Kota Ambon, harus memiliki segudang langkah dan strategis yang jitu, 
bukan saja sosialisasi secara manual, pemanfaatan dunia digital, dengan tujuan untuk meminimalisir resiko bencana alam, oleh karena waktu dan tempat bencana tidak dapat diperkirakan. Bencana datang tiba-tiba, jadi sedini mungkin masyarakat harus terbiasa dengan sensasi bencana, agar supaya pengalaman-pengalaman yang dibubuhi dengan pengetahuan dan mitigasi yang memadai mampu menjadi bekal bagi masyarakat Kota Ambon.

Saran yang diberikan semata-mata bukan untuk mengkritik, tapi yang peneliti harapkan, dapat memberikan insight kepada Pemerintah dan juga kepada masyarakat. Adapun saran yang diberikan sebagai berikut: Sosialisasi yang diberikan harus intensif, dan dilakukan di semua titik lokasi, agar supaya terjadi pemerataan baik secara kuantitas maupun kualitas. Sumber daya manusia, perlu ditambahkan jumlah maupun perlu ditingkatkan lagi mengenai pemahaman pra dan paskah bencana. Anggaran yang terbatas kiranya mampu dikelolah, kualitas pekerjaan tidak bersumber hanya pada anggaran. Pemilihan media sosialiasi yang beragam juga harus efektif dan efisien, kemampuan menyerap infromasi oleh masyarakat harus dipastikan benar-benar teraplikasikan.

\section{DAFTAR PUSTAKA}

Amri, A.B. (2010, Agustus 2). Waspada, Maluku Tengah dan Ambon Rawan Bencana Alam. Kontan.co.id. https://nasional.kontan.co.id/news/waspada-maluku-tengah-danambon-rawan-bencana-alam-1

Arimastuti, A. (2011). Tahapan Proses Komunikasi Fasilitator Dalam Sosialisasi Pengurangan Risiko Bencana (Studi Kasus Terhadap Tim Compress LIPI dalam Pelatihan Evakuasi Mandiri bagi Masyarakat Pantai terhadap Bahaya Tsunami (Pra Tsunami)). Jurnal Penanggulangan Bencana, 2(2), 15-23. Diperoleh dari https://bnpb.go.id/uploads/migration/pubs/380.pdf

Cangara, H. (2014). Pengantar Ilmu Komunikasi Edisi Kedua. PT Raja Grafindo Persada. Jakarta.

Fadhli, A. (2019). Mitigasi Bencana. Penerbit Gaya Media.

Firman, T. (2018, Agustus 8). Bagaimana Jepang Bersahabat dengan Gempa Bumi dan Tsunami. tirto.id. https://tirto.id/bagaimana-jepang-bersahabat-dengan-gempabumi-dan-tsunami-cQDa

Hidayati, D. (2008). Kesiapsiagaan Masyarakat: Paradigma Baru Pengelolaan Bencana Alam di Indonesia. Jurnal Kependudukan Indonesia, 3(1), 69-84. Diperoleh dari https://ejurnal.kependudukan.lipi.go.id/index.php/jki/article/view/164

Idrus, M. (2009). Metode Ilmu Penelitian Sosial, Pendekatan Kualitatif dan Kuantitatif. Erlangga. 
Irawanto, B. (2017). Menyibak Cakrawala Komunikasi: Sebagai Antologi Teori. Program Studi Magister Ilmu Komunikasi, UGM

Jones, P. (2010). Pengantar Teori-teori Sosial: Dari Teori Fungsionalisme hingga Postmodernisme (A.F. Saifuddin, Trans.). Yayasan Pustaka Obor Indonesia. (Karya asli diterbitkan 2003)

Lestari, P. (2007). Manajemen Komunikasi Bencana di Daerah Rawan Bencana (Studi pada bencana gempa bumi di Kecamatan Gantiwarno Klaten), Jurnal Ilmu Komunikasi Terakreditasi UPN "Veteran" Yogyakarta, 5(3), 197-209.

Lestari, P., Prabowo, A., \& Wibawa, A. (2012). Manajemen Komunikasi Bencana Merapi 2010 pada saat Tanggap Darurat. Jurnal Ilmu Komunikasi, 10(2), 173-197. Diperoleh dari http://jurnal.upnyk.ac.id/index.php/komunikasi/article/view/125

Moleong, L. J. (2019). Metodologi penelitian kualitatif. Remaja Rosdakarya.

Noor, D. (2014). Pengantar Mitigasi Bencana Geologi. Deepublish.

Patilima, H. (2004). Metode Penelitian Kualitatif. Alfabeta.

Peraturan Menteri Dalam Negeri. (2006). Pedoman Umum Mitigasi Bencana. Badan Nasional Penanggulangan Bencana (BNBP). https://www.bnpb.go.id

Raditya, I.N. (2019, September 28). Sejarah Gempa Ambon Tahun 1674 yang Tewaskan Ribuan Orang. tirto.id. https://tirto.id/sejarah-gempa-ambon-tahun-a674-yangtewaskan-ribuan-orang-eiRT

Rakhmat, J. (2012). Psikologi Komunikasi. Remaja Rosdakarya.

Ramli, S. (2010). Pedoman Praktis Manajemen Bencana (Disaster Management). Dian Rakyat.

Subagyo, P.J. (2006). Metode penelitian : dalam teori dan praktek. Rineka Cipta.

Sugiyono. (2012). Metode Penelitian Kuantitatif, Kualitatif dan R\&D. Alfabeta.

Solihat, M. (2008). Komunikasi Massa dan Sosialisasi. Mediator: Jurnal Komunikasi, 9(1), 105-112. https://doi.org/10.29313/mediator.v9i1.1143

Usman, H., \& Akbar, P.S. (2009). Metodologi Penelitian Sosial. Bumi Aksara.

Yin, R.K. (2009). Studi kasus: Desain dan metode. Rajagrafindo Persada 